\title{
Advanced nonlinear engine speed control systems
}

\author{
Vesterholm, Thomas; Hendricks, Elbert
}

Published in:

Proceedings of the American Control Conference

Link to article, DOI:

10.1109/ACC.1994.752335

Publication date:

1994

Document Version

Publisher's PDF, also known as Version of record

Link back to DTU Orbit

Citation (APA):

Vesterholm, T., \& Hendricks, E. (1994). Advanced nonlinear engine speed control systems. In Proceedings of the American Control Conference (Vol. Volume 2, pp. 1579-1580). IEEE.

https://doi.org/10.1109/ACC.1994.752335

\section{General rights}

Copyright and moral rights for the publications made accessible in the public portal are retained by the authors and/or other copyright owners and it is a condition of accessing publications that users recognise and abide by the legal requirements associated with these rights.

- Users may download and print one copy of any publication from the public portal for the purpose of private study or research.

- You may not further distribute the material or use it for any profit-making activity or commercial gain

- You may freely distribute the URL identifying the publication in the public portal

If you believe that this document breaches copyright please contact us providing details, and we will remove access to the work immediately and investigate your claim. 


\title{
Advanced Nonlinear Engine Speed Control Systems
}

\author{
Thomas Vesterholm and Elbert Hendricks \\ Institute of Automatic Control Systems, IACS \\ The Technical University of Denmark \\ DK-2800 Lyngby, Denmark \\ e-mail tv@sl.dth.dk
}

\begin{abstract}
Several subsidiary control problems have turned out to be important for improving driveability and fuel consumption in modern spark ignition (SI) engine cars. Among these are idle speed control and cruise control. In this paper the idle speed and cruise control problems will be treated as one: accurately tracking of a desired engine speed in the presence of model uncertainties and severe load disturbances. This is accomplished by using advanced nonlinear control techniques such as input/output-linearization and sliding mode control. These techniques take advantage of a nonlinear model of the engine dynamics, a Mean Value Engine Model (MVEM), reported in earlier publications.
\end{abstract}

\section{Introduction}

The dynamics of the mean value of the most important states of an SI engine can be written in the form [1]

$$
\begin{aligned}
& n=f_{1}\left(n, p_{\operatorname{man}}\right)+g_{1}\left(n, p_{\operatorname{man}}\right) u \\
& p_{\text {man }}=f_{2}\left(n, p_{\operatorname{man}}\right)+g_{2}\left(p_{\operatorname{man}}\right) u
\end{aligned}
$$

where $n$ is the engine crank shaft speed, $p_{\operatorname{man}}$ is the intake manifold pressure and the $f_{i}$ 's and $g_{i}$ 's are nonlinear functions in the states $n$ and $p_{\operatorname{man}}$ [1]. The control input $u$ is in this case $\cos (\alpha)$, where $\alpha$ is the throttle position in degrees.

The main problem when dealing with the control of nonlinear dynamical systems is to achieve a representation which at the same time is reasonably simple and accurate. A well known method to achieve this is by linearizing the system around an operating point of interest. This type of linearization has, however, a limited region of validity. Thus, in order to solve the general speed reference tracking control problem it would require the use of several linearized submodels to cover the entire operating range of the engine. In this way the controller would be designed based on different submodels leading to an operating point dependent feedback law.
Recently some alternative linearization techniques have been presented in the literature [2],[3]. These linearization techniques, known as input/outputlinearization (I/O-L), have in general a larger range of validity. Using I/O-L it is possible to achieve a linear representation of the model (1) which is valid over the entire operating range of the engine.

\section{Controller Design}

In an earlier paper different control designs based on either of the linearization techniques mentioned above have been tested in the idle speed region [4]. From this paper it has become clear that for a specific operating point both linearization methods leads to satisfactory results. The main advantage of using the I/O-L techniques is that only one design need be carried out to cover the entire operating range of the engine i.e. both the idle speed and cruise control regions. In order to achieve robustness with respect to parameter uncertainties and disturbances the use of sliding mode control has been adopted.

Considering the crank shaft speed as the output of the model (1) the I/O-L design can be easily carried out. The derivative of the output with respect to time is simply the first state equation. This state equation is directly affected by the input, $u$, i.e. the relative degree of the system is 1 [2]. Introducing the virtual input $v$

$$
v=f_{1}\left(n, p_{\operatorname{man}}\right)+g_{1}\left(n, p_{\operatorname{man}}\right) u
$$

In this new input the system (1) has now been partly linearized. The remaining part of the system is rendered unobservable by the linearization. It can be verified that this part of the system is stable for the operating range of interest and will thus be neglected in the remaining design.

The system model (1) has been derived assuming that the engine runs with a stoichiometric air/fuel (A/F) ratio. This is accomplished using A/F-ratio controllers reported earlier [4],[5],[6].

Using sliding mode control (SMC) design it is now 1axo possible to achieve a controller with anantifiahle 
stability and performance robustness properties [3]. Slidning mode controllers are usually of a very high gain nature. In this case it is important to keep in mind that there is already one feedback loop in the system keeping track of the A/F-ratio. For this reason it is necessary to choose more moderate feedback gains for the loop to be designed. In general this will degrade the tracking performance of the controller. This problem is solved by introducing integral action in the loop. The sliding variable is then

$$
\mathbf{s}=\tilde{\mathbf{n}}+\lambda \int_{0}^{t} \tilde{n d r}
$$

where $\tilde{n}=\mathbf{n}-n_{d}, n_{d}$ is the reference RPM, $\lambda$ is a design parameter determining the dynamics on the sliding manifold $s=0$.

Designing for attractiveness of the boundary layer $|s| \leq \Phi$ the resulting control law becomes, [2]

$$
\mathbf{u}=k \operatorname{sat}\left(\frac{s}{\Phi}\right)-\frac{\lambda \tilde{n}+f_{1}\left(n, p_{\operatorname{man}}\right)}{g_{1}\left(n, p_{\text {man }}\right)}
$$

corresponding to $\mathrm{v}=-\lambda \tilde{n}$ with an additional sliding term.

\section{Practical Verification}

The controller has been tested on a 1.2751 British Leyland engine. In order to verify the "global" validity of the design the test was run at several operating points. In an earlier paper, the design was shown to be acceptable in the idle speed region [4]. Figures 1 and 2 show the response of the same SMC to a step load changes.
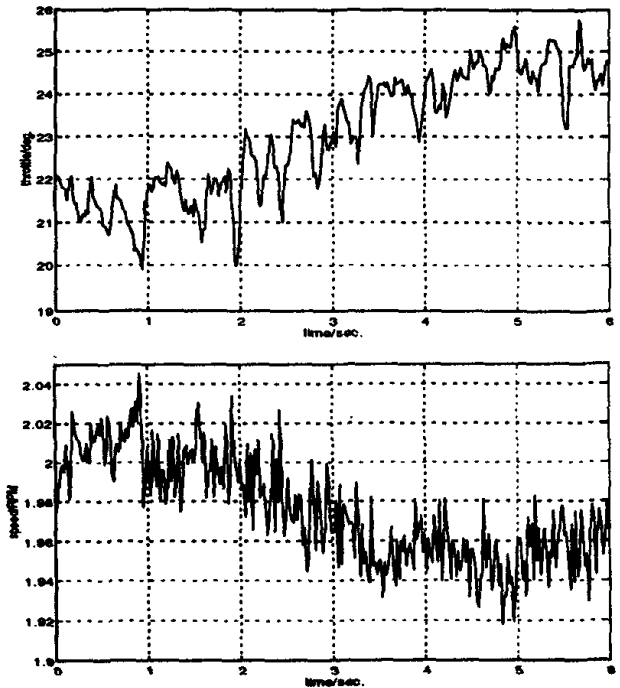

Figure 1. Response of SMC to a 9 to $11.5 \mathrm{kw}$ load change (in 1 sec.), 2000 RPM.

In both Experiments a step change on the order of $25 \%$ were introduced in the load at time $t=2 \mathrm{sec}$.
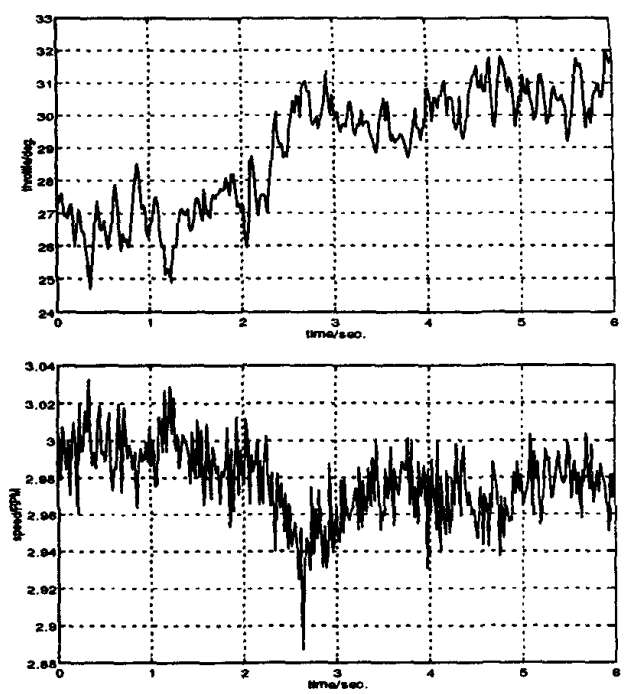

Figure 2. Response of SMC to a 12 to $15 \mathrm{kw}$ load change (in $1 \mathrm{sec}$ ), 3000 RPM.

As can be seen on the figures, the SMC responds in a reasonably accurate fashion even if the operating conditions are quite different.

\section{Conclusion}

The use of slidning mode controller design for the genreal SI engine speed problem has been tested. The results verifies that this technique leads to satifactory results. The main advantage achieved when using sliding mode control for this problem is the global applicability of the design.

\section{References}

[1] E. Hendricks and S.C. Sorenson, "SI Engine Control and Mean Value Engine Modelling", SAE Technical Paper No. 910258, 1991.

[2] A. Isidori, Nonlinear Control Systems: An Introduction, $2^{\text {nd }}$ Edition, Springer Verlag, 1989.

[3] J-J. E. Slotine and W. Li, Applied Nonlinear Control, Prentice-Hall Inc., 1991.

[4] S. Nielsen, L. Kjergaard, T. Vesterholm and E. Hendricks, "Advanced Nonlinear Engine Idle Speed Control Systems", SAE Technical Paper No. 940974 , 1994.

[5] T. Vesterholm and E. Hendricks, "SI Engine Observers Realized using Optimized Integration Algorithms", IFAC, 1993.

[6] P. Kaidantzis, P. Rasmussen, M. Jensen, T. Vesterholm and E. Hendricks, "Robust SelfCalibrating Lambda Feedback for SI Engines", SAE Technical Paper No. 930860, 1993. 